\title{
KRITIK TERHADAP HUKUM ISLAM (Ke Arah Rekonstruksi Epistemologis)
}

\section{Arifin S.}

(Dosen Tetap STAIN Watampone, Sulawesi Selatan, Indonesia, email: arifinsahaka.iainbone@gmail.com)

\section{Abstract}

Talking about Islam, must be talking about Islamic law. Why? Because Islamic law is important and significance segment of Islam. Nobody can understand Islam perfectly without understanding about Islamc Law. According to Moslem, Islam (based on Quran and sunnah) is the one of reveled religion whose has a comprehensive and perfect reference. Every thing is covered and explained by them. It means no thing lost from attention of Islam. Its the major claim of Moslem for along time.

Meanwhile, the reality showed that Islam is very late (not to say out of thing wrong by Islam (read Islamic law).

In this case there are two assumption which cause Islam law is Questioned. First, Islamic law is always say as a universal law, perennial and a histories. The second one, Islamic law is created by God and steril from human intervention. Its consequence is Islamic law cannot accept progressing of public and private law. In writer's mind there is a mistake in Islamic law epistemology. To make Islamic law up to date, begin from reconstruction of epistemology. To make Islamic law up to date, begin from reconstruction of epistemology. This is concern of this research.

\section{Kata Kunci: Hukum Islam, Rekonstruksi, Epistemologi}




\section{PENDAHULUAN}

Bagi kaum Muslimin, Islam, dengan platform al-Qur'an dan sunnah, diyakini sebagai satu-satunya agama samawi (agama yang datang dari Tuhan) yang memiliki referensi wahyu yang paling komprehensif. Tak satu segmenpun terlewatkan dalam usaha referensi tersebut, baik dalam bentuk ulasan yang sangat detail maupun dalam bentuk rumusan yang global. Hal ini tentu saja berbeda jika dibandingkan dengan agama samawi lain seperti yahudi dan Nasrani, yang sangat limited dalam menyodorkan referensi wahyu apabila jika disandingkan dengan agama ardhi (agama yang muncul dari kreatifitas manusia). Karakteristik ketercakupan ini terkait erat dengan kedudukan Islam sebagai agama pemungkas yang secara filosofis harus menjanjikan ketersediaan rujukan yang tidak hanya untuk kekinian tetapi juga kedepannya (futuristik).

Namun demikian, keunggulan Islam berikut derivasinya, mengimplisitkan satu rekomendasi penting bagi umat Islam, yaitu bagaimana wujud aktualitas itu dalam berbagai dimensi kehidupan. Hal ini sudah barang tentu, menuntut keseriusan dan kerja keras ummat Islam dalam menelaah, mengkaji dan memformulasikan ajaran-ajarannya. Di sinilah metodologi kajian terhadap Islam yang terus diverifikasi menemukan urgen vitalnya. Islam, sangat niscaya untuk dikaji dari sudut pandang dan paradigma yang bervariatif. Variasi pendekataan dalam pemahaman terhadap Islam secara lebih artikulatif dan kaffah. Jika tidak kesan stagnan tidak bisa dielakkan.

Hukum Islam sebagai bagian integral dalam Islam yang dianggap sebagai dimensi terpenting dari ekspresi pengalaman keberagaman manusia sesudah tauhid, baik dalam konteks kehidupan individual eksklusif, maupun dalam kehidupan komunal-inklusif tidak boleh tidak, harus menyahuti issu keniscayaan didekati dengan berbagai pendekatan tersebut. Jika tidak, hukum akan bergerak ditempat dan tidak akomodatif. Padahal kedudukan hukum Islam demikian strategis.

Dikalangan orientalis, Schacht misalnya, hukum Islam ditempatkan sebagai konklusi dari keseluruhan pemikiran Islam dan entitas Islam itu sendiri. Konsekuensi logis dari konotasi Schacht tersebut adalah bahwa seseorang tidak mungkin dapat 
memahami Islam secara komprehensif tanpa memahami relungrelung hukum Islam itu sendiri. ${ }^{1}$ Secara enigmatic Taufik Adnan Amal memberi kualifikasi terhadap hukum Islam sebagai pengetahuan par-excellence. ${ }^{2}$ Sementara itu Gibb, memberikan kualifikasi bahwa, hukum Islam sebagai media yang paling efektif dalam mengokohkan tatanan sosial dan kehidupan masyarakat bangsa muslim. Bahkan lebih dari itu, hukum Islam memiliki moral platform yang luhur secara laten menjadi front terdepan menghadapi gonjang-ganjing (fluktuasi) politik. ${ }^{3}$

Secara teoritis, posisi ideal hukum Islam tersebut sangat bisa menyahuti gempita zaman dengan segenap dinamikanya (granted). Hanya saja garansi tersebut dewasa ini kian gencar dikritik, terutama dari kalangan teoritis hukum moder. Ada kesan bahwa hukum Islam tidak lagi menyuarakan mainstream wacana hukum public yang steril dari diskriminasi, bias gender, ras dan agama.

Menurut penulis sorotan tersebut bukan tanpa alasan. Setidak-tidaknya terdapat dua persoalan epistemologi mendasar yang perlu dikaji ulang. Pertama, hukum Islam (baca: fiqh) dianggap sebagai hukum universal dan abadi bagi umat Islam. Hukum Islam (fiqh) dipahami sebagai sabda suci yang a-historis dan sudah tersaji dalam bentuk jadi. Kedua, hukum Islam yang dianggap abadi dan telah tercipta pada zaman azali tersebut, diposisikan secara vis a vis dengan hukum sekuler modern yang dipandang non Ilahi. Kekeliruan cara pandang terhadap hukum Islam ini secara et officio berimplikasi pada ushul fiqh sebagai metodologi hukum Islam (al-Ahkam al-Asasiyyah). Apakah tidak mungkin metodologi uhukum Islam itu diperkaya dengan teori-teori sosial (antropologi, sosiologi, dan sejarah) yang notabene tidak dalam aksara Arab? Dari sinilah upaya ke arah rekonstruksi epistemologi hukum Islam bermula.

${ }^{1}$ Lihat Joseph Schacht, An Introduction to Islamic Low (London: Oxford University Press, 1971), h. 1.

${ }^{2}$ Lihat Taufik Adnan Amal, Islam dan Tantangan Modernitas, Studi Atas Pemikiran Fazlur Rahman (Bandung: Mizan, 1989), h. 23.

${ }^{3}$ Lihat H. A. R. Gibb, Mohammedanism: An History Survey (London: Oxford University Press, 1989), h. 7-8. 


\section{PEMBAHASAN}

\section{A. Sekilas Tentang Epistemologi}

Epistemologi adalah salah satu cabang filsafat secara khusus berbicara seputar teori ilmu pengetahuan. Ada tiga hal yang menjadi sentral kajian dalam epistemologi, pertama, kajian tentang sejauh mana kekuatan akal pikiran (mind) dalam usahanya untuk memperoleh pengetahuan tentang dunia luar. Dalam hal ini dibicarakan tentang hakikat dan batas-batas kekuatan akal pikiran (the nature and limits of the power of the faculties of mind). Kedua, kajian tentang seberapa jauh kemampuan dan kekuatan akal pikiran dapat menembus struktur fundamental dari realitas (external world). Ketiga, seberapa tepat (valid) ide-ide atau konsep-konsep yang telah berhasil dirumuskan oleh akal pikiran dalam menggambarkan dan menjelaskan hakikat dan struktur fundamental dari suatu realitas (the extent to which the mind's ideas adequately represent the nature of external world). ${ }^{4}$

Hingga saat ini, telah berkembang tiga aliran epistemologi, pertama rasional (idealism), yaitu aliran pemikiran yang menekankan pentingnya peran "akal", "ide", "form" dan "category" sebagai sumber ilmu pengetahuan. Kedua, empirical (realism), yaitu aliran yang menekankan pada peran indera (sentuhan, penglihatan, pencicipan, penciuman, dan pendengaran) sebagai sumber sekaligus alat untuk memperoleh ilmu pengetahuan. Ketiga, intuitional (irasional), yaitu aliran yang menekankan pada pertimbangan intuisi dan wahyu sebagai sumber kebenaran ilmu pengetahuan. ${ }^{5}$

Dua aliran yang disebut pertama (rasional dan empirikal), mengalami perkembangan yang luar biasa sejak abad ke-17 Masehi. Bahkan dapat dikatakan bahwa kedua aliran epistemologi itu, merupakan kunci pokok (master key) bagi perkembangan kebudayaan dan peradaban Barat yang gilang gemilang. Sementara aliran yang disebut terakhir (intuisional), tidak begitu mendapat perlakuan simpatik di Barat, akan tetapi

${ }^{4}$ Lihat Muhammad Ali As-Sayyis, Tarikh Tasyri' al-Islamiy (Mesir: Maktabah Muhammad Abi Sabih wa Audah, 1975), h. 8-9.

${ }^{5}$ Lihat M. Amin Abdullah, Dasar-dasar Epistemologi (Pergseran Pemikiran Epistemologi dari Era Modern ke Era Kontemporer) (Yogyakarta: Pustaka Pelajar, 1999), h. 49. 
lebih banyak diminati di dunia timur (Islam), yang diduga turut memperlambat (untuk tidak mengatakan menghambat) capaiancapaian yang mengagumkan, kendatipun kitab suci al-Qur'an dengan sangat tegas menyatakan betapa ketiga model epistemologi itu harus seiring-sejalankan. ${ }^{6}$

Dalam Islam, terminologi ketiga epistemologi di atas dikenal dengan burhani untuk menyebut epistemologi rasional, bayani untuk menyebut epistemologi empirical dan irfani untuk menyebut epistemologi intuisional.

\section{B. Epistemologi Hukum Islam: Dikotomi samawi dan Wad'iy}

Dalam diskursus klasik hukum Islam, selalu saja muncul pembahasan tentang tasyri' samawi (devine law) yang secara tegas dibedakan dengan tasyri' wad'iy (human law). Perbedaan yang tegas ini melahirkan dua polarisasi kategori hukum. Pertama, hukum yang diturunkan oleh Tuhan. Kedua, hukum yang ditemukan oleh manusia. Pada polarisasi hukum model pertama, hukum itu diyakini turun kepada ummat manusia dalam bentuk jadi yang tidak menerima campur tangan siapa pun (otoritas Tuhan). Sementara polarisasi yang disebut belakangan, hukum itu ditemukan oleh umat manusia lewat pemikiran, rancangan, dan perundangan yang tidak kait-mengait sama sekali dengan janji dan ancaman Tuhan (sekuler). ${ }^{8}$ Pembedaan ini galib muncul dalam perjalanan sejarah hukum Islam.

Ali as-Sayyis misalnya, membuat pemilahan antara kedua tasyri' tersebut dengan mendefinisikan tasyri' samawi sebagai kumpulan perintah, larangan, petunjuk dan prinsipprinsip yang ditetapkan Tuhan untuk manusia melalui rasul utusannya yang menjanjikan pahala bagi yang mentaati, ancaman siksa bagi yang mengingkarinya. Sedangkan tasyri'

${ }^{6}$ Lihat Jujuj S. Suriasumantri, Filsafat Ilmu Sebuah Pengantar Populer (Jakarta: Sinar Harapan, 1997), h. 54.

${ }^{7}$ Beberapa statement al-Qur'an yang dapat dirujuk untuk mencerminkan ketiga model epistemology tersebut, diantaranya QS. al-Rum: 8 (rasional), QS. Al-Rum : 22 (empirical), dan QS Al-Taghabun: 11 (intuisional). Selengkapnya lihat Departemen Agama RI, Al-Qur'an dan Terjemahnya (Semarang: Toha Putra, 1989), h. 490.

${ }^{8}$ Lihat Muhammad Abid al-Jabiry, Bunyah al-'Aql al- 'Araby (Beirut: al-Markaz al-Tsaqfa al-‘Araby, 1979), h. 250-253. 
wad'iy adalah aturan-aturan yang ditetapkan oleh manusia atau pemerintah untuk diberlakukan kepada rakyatnya. ${ }^{9}$

Jika ditelusuri, rumusan di atas, tentu saja mudah ditebak mereferensi atau setidak-tidaknya dipengaruhi oleh opini teoritis muslim sebelumnya seperti al-Qarafi al-Razi. Mereka bahkan mengatakan bahwa hukum Islam bersift qodim dan tidak diciptakan. Hal ini semakin memberikan kesan bahwa hukum Islam sudah ada sebelum manusia diciptakan. Implikasi lanjutannya adalah bahwa konstruksi pemikiran demikian membentuk public image bahwa hukum Ilahi mendahului dan tidak didahului oleh masyarakat. ${ }^{10}$

Jika cara pandang di atas digiring kepada persoalan epistemologi, yaitu tentang dari mana sumber dan proses yang mengantarkan manusia kepada pengetahuan yang sah tentang hukum, maka kecenderungan klasik itu sangat jelas bersifat subjektivisme-teistik. Aliran subjektifistik-teistik ini menegaskan bahwa hukum hanya bisa diketahui lewat wahyu yang dibawa oeh Nabi Muhammad yang terdokumentasi pada al-Qur'an dan sunnah. Keyakinan demikian pada gilirannya berimbas kepada penggiringan fokus wacana hukum Islam kepada penganalisaan an sich terhdap teks-teks al-Qur'an sunnah tersebut (analisa linguitic berikut logika bahasanya). Sekedar diketahui saja bahwa makna bahasa pun (baca bahasa Arb) baik leksikal maupun gramatikal sangat historis.

Tidak hanya itu model keyakinan subjektifistik-teistik ini secara reflek turut andil dalam memformat paradigma kaum muslimin yang berimplikasi pada munculnya dikotomi yang dominan antara undang-undang yang dibuat oleh negara dan undang-undang yang dibuat oleh teoritisi Muslim (baca; fuqaha). Jika undang-undang negara dianggap buatan manusia maka hukum Islam (fiqh) dianggap buatan Tuhan.

Ketegangan antara dualitas tersebut tentu saja tidak mudah diminimalisir apalagi dikikis habis dari umat Islam. Di Indonesia, proses ratifikasi terhadap undang-undang Perkawinan 1974 merupakan contoh yang paling sederhana untuk membuktikan pandangan dikotomis tersebut. Pencatatan

\footnotetext{
${ }^{9}$ Lihat, Ibid., h. 254.

${ }^{10}$ Lihat M. Maslehuddin, Philosophy of Islamic Law and Orientalist (Delhi: Taj Company, 1986), h. 55.
} 
perkawinan, pembatasan poligami dan pengetatan perceraian, awalnya dicurigai sebagai upaya sekularisasi terhadap umat Islam. Karena dianggap sebagai produk hukum manusia bukan produk hukum Tuhan. Dualistis tersebut semakin tidak terbantahkan ketika menilai status perkawinan bawah tangan (nikah sirri) yang dinilai sebagai perkawinan yang "sah secara agama tetapi tidak sah menurut negara".

Umat Islam yang sudah dicecar dengan sikap dikotomi ini cenderung menganggap bahwa berbagai produk perundangundangan yang secara konstitusional tidak menyatakan diri sebagai negara Islam, baik adari UUD hingga peraturan organic lainnya, tidaklah berdosa jika tidak ditaati. Hal yang amat berbeda dengan fiqh yang bagi mereka harus diterima secara taken for granted (bi laa kaifa).

Sesungguhnya lembaran sejarah Islam paling awal telah memaparkan, betapa kelahiran hukum Islam (yang bersumber pada al-Qur'an dan hadis) inklusif dan berkaitan dalam proses kenegaraan. Nabi Muhammad, sang Nabi, adalah sebagai kepala negara dan legislator sekaligus. Ia membangun institusi-institusi hukum dan perundang-undangan untuk mendukung penataan struktur masyarakat yang baru saja terbentuk, tanpa memberi embel-embel hukum agama (Tuhan) dan hukum negara (sekuler). Justru kelahiran sejumlah putusan beliau yang terkait dengan pola relasi antara sesama masyarakat dan masyarakat dengan negara secara integratif memuat nilai-nilai Ilahiah, seperti hukum perdata (muamalah), hukum bela negara (jihad), hukum pidana (jinayah), hukum kewarisan (mawarits), hukum wasiat (wasiyah), hukum perkawinan (munakahat) dan hukum peradilan (qadhi). ${ }^{11}$ Bahkan dalam banyak kasus proses legislasi pada masa rasul merupakan respon langsung terhadap situasi pada saat itu yang dituangkan dalam bentuk sodoran nash maupun sikap akomodatif (persetujuan). Tegasnya, eksistensi hukum cukup efektif dalam upaya mengubah, menata, menentukan dan mengontrol kondisi sosial-kultural masyarakat Arab.

Namun demikian, seraya setelah wafatnya Nabi, teksteks yang sudah tersedia dalam al-Qur'an dan hadis mulai dirasa

\footnotetext{
${ }^{11}$ Lihat, Ibid., 23.
} 
tidak mampu lagi menjangkau relung-relung persoalan aktual yang dihadapi. Padahal pada saat yang bersamaan tuntutan terhadap tersedianya hukum yang mampu menata kehidupan sosial sangat mendesak. Pergesaran-pergeseran yang penting yang terjadi pasca Nabi Muhammad yang pada dasarnya bias oleh format politik, perluasan wilayah dan perseteruan internal uma Islam memicu upaya kreatif para sahabat untuk melakukan penafsiran terhadap doktrin-doktrin hukum yang pernah diwariskan Nabi. Hadis Muaz bin Jabal yang menjelaskan tentang lisensi berijtihad, dipandang menjadi ruh dan justifikasi terhadap usaha-usaha kreatif sahabat.

Contoh yang paling antik adalah peristiwa penaklukan Syiria pada masa pemerintahan khalifah Umar bin Khattab. Umar dihadapkan pada persoalan dilematik, antara memberikan tanah rampasan perang kepada para tentara yang berjuang atau membiarkan tetap dikelola oleh penduduk setempat dengan catatan memberikan sewa (kharaj) kepada negara. Pilihan Umar untuk membiarkan tanah rampasan perang ditangan penduduk asli mendapat perlawanan hebat dari para sahabat. Tidak sampai disitu, kejutan-kejutan hukum terus digulirkan Umar, seperti kasus muallaf dan penangguhan hukuman potongan tangan bagi pencuri. ${ }^{12}$

Ketika Dinasti Arab Islam meliputi daratan Syiria, Irak, dan Mesir, sekitar pertengahan abad pertama hijriah, format politik Islam mengalami perubahan yang signifikan, terlebihlebih pasca kekalahan politik Ali dari Muawiyah, menimbulkan sikap akomodasi terhadap praktek-praktek hukum regionallokal. ${ }^{13}$ Demikian pula halnya dengan kota Kuffah, yang tampil sebagai kota kosmopolit dengan ragam persoalan yang sangat asing bagi kota seperti Hijaz. Ulama-ulama Damaskus dan Kuffah, bekerja keras untuk merespon persoalan dengan berbagai argumentasi yang dapat diterima oleh masyarakat setempat yang belum tentu dapat diterima masyarakat kota Hijaz. Dalam situasi inilah, hukum Islam mencapai posisi yang

${ }^{12}$ Lihat Anwar al-Qadry, Islamic Jurispudence in The Modern World (Lahore: Ashraf Press, 1997), h. 53.

${ }^{13}$ Lihat NJ. Coulson, A History of Islamic Law (Bandung: Edinburg: Edinburg University Press, 1998), h. 28. 
paling penting dalam sejarahnya. Pada masa inilah hukum Islam mengalami fase formatisasi yang luar biasa.

Melihat setting histories di atas, tampaknya hukum Islam tidaklah dibuat dan diturunkan oleh Tuhan tetapi oleh manusia. Sehingga benar yang dikatakan oleh Ahmad Hassan, bahwa hukum Islam yang sesungguhnya dibentuk oleh tangan tabi' in melalui aplikasi ijtihad yang bebas dan kreatif. ${ }^{14}$

Hanya saja, perkembangan yang pada mulanya yang luar biasa di atas didasari oleh aksi-aksi kesetiaan masyarakat terhadap hasil-hasil pemikiran para tokoh mereka, yang pada gilirannya membuahkan mazhab-mazhab hukum regional lokal baik di Hijaz (Maliki), Irak (Hanafi), maupun di Syiria (Hanbali). Di Hijaz, "praktek penduduk Madinah" atau amalan penduduk Madinah menjadi inspirasi dan prioritas utama dalam menemukan dan menurunkan hukum. Sementara di Irak dan Syiria, sangat memberikan tempat kepada pertimbangan kepentingan masyarakat lokal.

Kendatipun pada mulanya kreatifitas para teoritis hukum kaum muslimin ini menjadi modal bagi kejayaan hukum Islam, namun dengan aksi-aksi kesetiaan yang muncul belakangan, menjadikan hukum Islam justru sebagai ajang tarik ulur hegemoni mazhab yang oleh Syafi'i ditentang habishabisan dengan membuat formulasi hukum Islam yang lebih elegan. Hanya saja pada kenyataannya, capaian maksimal Syafi'i di bidang hukum Islam terjebak pada pembentukan mazhab baru di tangan pengikutnya (mazhab Syafi'i). Dari sinilah bermula bencana kemandekan hukum Islam. Sejak itu, praktis pergerakan ke arah perkembangan hukum Islam mulai terhenti yang diperparah dengan kolonisasi bnagsa-bangsa Eropa. Kondisi ini diperparah dengan salah kaprah umat Islam dalam mengikuti alur sistem kodifikasi perundang-undangan yang diperkenalkan bangsa Eropa, yang kemudian memaksakan hukum Islam ikut-ikutan menjadi kitab undang-undang hukum. ${ }^{15}$

${ }^{14}$ Lihat A. Hassan, Pintu Ijtihad Sebelum Tertutup (Bandung: Pustaka, 1997), h. 41.

${ }^{15}$ Lihat Nizamuddin Abdul Hamid, Mafhum al-Fiqh al-Islamiy (Beirut: Muassasah al-Risalah, 1985), h. 39. 
Sebagai akibat terlalu lamanya Islam berada dalam telikung bayang-bayang Eropa, maka ekspresi kemarahan terwujud dalam pernyataan truth claim bahwa model perundangundangan yang dibangun oleh dunia Barat adalah non Islami, oleh karenanya harus dihindari. Satu-satunya model perundangundangan yang falid adalah figh. Mengikuti undang-undang yang diproduk oleh negara dianggap tidak berdasar.

\section{Rekostruksi Epistemologi Hukum Islam}

Memperbincangkan epistemologi hukum Islam, ${ }^{16}$ pada akhirnya berbicara tentang proses cara penemuan sesuatu hukum dalam Islam yang dalam diskursus filsafat ilmu disebut dengan metodologi (ushul fiqh). ${ }^{17}$

Secara jujur harus dikatakan bahwa selama ini dominasi teks al-Qur'an dan hadis sedemikian rupa besarnya yang pada gilirannya menggiring metodologi hukum Islam (ushul fiqh) kepada pendekatan yang serba teks pula. Bahkan yang lebih disayangkan, metodologi hukum Islam pun harus dikait-kaitkan dengan kualifikasi halal-haram. Akibatnya, substansi persoalan justru menjadi tidak jelas. Diantara bukti pendekatan yang seba teks itu adalah konstruksi pemilahan nash ke dalam qathiy'dan dzanny. Dengan pemilahan seperti itu, ayat al-Qur'an yang menyatakan "anak laki-laki dua bagian dari anak perempuan" dipandang sebagai nash qath'iy. Akibatnya tidak diperkenankan interpretasi lain. Padahal pada sisi lain,

${ }^{16}$ Epistemologi adalah salah satu cabang filsafat yang secara khusus berbicara seputar teori ilmu. Ada tiga hal yang menjadi sentra kajian dalam epistemology. Pertama, kajian tentang sejauhmana kekuatan akal pikiran (mind) dalam usahanya untuk memperoleh pengetahuan tentang dunia luar. Dalam hal ini dibicarakan tentang hakikat dan batas-batas kekuatan akal pikiran (the nature and limits of the power of the faculties of mind). Kedua, kajian tentang seberapa jauh kemampuan dan kekuatan akal pikiran dapat menembus struktur fundamental dari realitas (eksternal world). Ketiga, seberapa tepat (valid), ide-ide atau konsep-konsep yang telah berhasil dirumuskan oleh akal pikiran dalam menggambarkan dan menjelaskan hakikat dan struktur fundamental dari suatu realitas (the extent to which the midn's ideas adequately represent the nature of external world).

${ }^{17}$ Metode merupakan suatu prosedur untuk mengetahui sesuatu dengan langkah-langkah yang sistematis. Ilmu yang berbicara tentang metode disebut dengan metodologi. Metodologi merupakan bagian dari diskursus epistemologis. Dalam studi hukum Islam, metodologi disebut sebagai ushul fiqhi. 
penyimpulan yang demikian bisa saja dihadapkan pada semangat lain, misalnya saja komitemen Islam yang berupaya mengangkat harkat dan martabat perempuan. Atas perkembangan mutakhir, dimana peluang sama-sama dimiliki oleh laki-laki dan perempuan untuk menguasai sumber-sumber penghasilan. Berdasarkan kegelisahan di atas, maka sesungguhnya lebih tepat jika ditangkap dari suatu nash adalah pesan hakikinya, yaitu keharusan melakukan pembagian harta warisan kepada yang berhak menerimanya secara adil, bukannya dua banding satu sebagai kenyataan real tekstual. Dengan demikian, apa yang dikatakan qath'iy adalah sangat memungkinkan untuk diinterpretasikan (dzanny). Hal itu juga bermakna bahwa pemilahan kepada qath'iy-dzanni, sesungguhnya buah dari pemahaman yang sangat tekstualis dari teks-teks nash yang jelas-jelas sangat mereduksi kedalaman makna yang terkandung di dalamnya.

Kekeliruan yang sama terjadi pada pemilahan nash kepada muhkam dan mutasyabiat. Muhkam diartikan dengan nash-nash yang sudah memiliki makna yang jelas, meyakinkan, tidak menerima ta'wil (interpretasi alegoris) dan naskh (pembatalan). Sementara mutasyabihat dimaknai dengan nashnash yang masih menyimpan sejuta misterius.

Beberapa ayat yang sudah terlanjur dinilai muhkam adalah, potong tangan bagi pencuri (QS. al-Maidah: 41) dan cambuk seratus kali bagi pezina (QS. An-Nur: 2). Sementara ayat-ayat yang bernuansa mutasyabih misalnya, kata-kata alif lam ra, dan kata quru' dalam surah al Baqarah ayat 228.

Jika ditelusuri secara mendalam, maka sesungguhnya kata potong tangan pada kasus pencurian, merupakan sebuah bentuk resepsi-akomodatif terhadap khazanah hukuman yang berlaku pada masyarakat Roma, kuno, yang dipinjam oleh Islam sekedar memenuhi rasa keadilan masyarakat yang baru saja terbentuk pada waktu itu. Ketika itu supremasi hukum belum didukung oleh institusi-institusi terkait, sehingga belum cukup piranti untuk membuat rumusan hukum baru yang khas milik Islam. Artinya target awal pada waktu itu adalah bagaimana keadilan hukum bisa ditegakkan bagi siapa saja pelaku kejahatan. Jadi, kata kuncinya adalah keadilan. Sementara pilihan potong tangan di dalam nash merupakan suatu bentuk 
alternatif saja yang sangat mungkin untuk dikembangkan. Konklusi selanjutnya adalah bahwa produk hukum sangat terkait dengan historitas suatu masyarakat.

Contoh yang paling aktual adalah zakat pertanian. Dalam literatur fiqh klasik zakat bagi hasil pertanian adalah 10 $\%$ bagi pertanian dengan metode tadah hujan dan $5 \%$ bagi pertanian yang menggunakan irigasi.

Konsep fiqh seperti ini sudah berlangsung 15 abad nyaris tanpa koreksi. Jika presentasi di atas dipahami dalam konteks masyarakat Islam awal dahulu, dimana primadona penghasilan terletak pada sektor pertanian, maka persentase yang relatif besar tersebut cukup dapat diterima sebagai sumber devisa negara. Akan tetapi jika dikaitkan dengan konteks kekinian, dimana sumber-sumber produksi tidak hanya pada sektor pertanian, tetapi juga perdagangan, industri, pertambangan, perkebunan, maka patokan persentase di atas adalah sangat memberatkan dan tidak fair, karena relatif terlalu besar. Tidak hanya itu, rasio persentase bagi pertanian yang menggunakan model irigasi sudah saatnya untuk lebih tinggi daripada pertanian tadah hujan. Alasannya adalah bahwa pertanian irigasi bisa memberikan hasil dan frekuensi panen yang maksimal jika dibandingkan dengan tadah hujan.

\section{PENUTUP}

Starting point para kritisi hukum Islam terletak pada kelatahan ummat Islam yang mengatakan hukum Islam itu pasti, kekal dan abadi. Padahal kenyataan menunjukkan bahwa hukum Islam itu selalu bergerak seiring dengan pergerakan dan perubahan masyarakat. Ibarat jarum jam, maka hukum tidak boleh berhenti merespon zamannya. Jelasnya apresiasi yang tinggi terhadap kesempurnaan sebuah hukum diukur dari sejauh mana hukum Islam mampu memenuhi hasrat sosial sesuai dengan fakta-faktanya. Inilah yang kemudian disebut-sebut sebagai premis yang bercita rasa modern-sekuler.

Namun bagi sebagian besar umat Islam, premis demikian tidak begitu diminati lantaran dianggap kering dari dimensi transedental. Berbeda halnya dengan fiqh, yang menurut mereka sangat kaya nilai-nilai transendental dan sangat tidak sekuler. Argumentasinya adalah justifikasi pada akhirnya telah menyempitkan ruang gerak hukum Islam yang harus 
mengalami takdir buruk berupa keterfokusan kepada persoalan ibadah ritual. Karena hanya persoalan ibadah yang mendapat justifikasi nash secara lengkap. Padahal fakta menunjukkan bahwa perjalanan fiqh sangat terkait dengan konteks yang melingkupi. Artinya fiqh mengalami proses evolutiv, tidak statis dan tidak final seperti yang diasumsikan selama ini.

Dengan demikian harus ada visi cerdas yang mencerahkan yang menempatkan fiqh dan hukum modern pada satu kesatuan yang organic. Visi yang dimaksud sekaligus akan meruntuhkan frame dikotomik. Hukum Islam antar samawi dan ardhi. Formulasi konkritnya adalah terciptanya hukum atau undang-undang yang dibuat oleh manusia tetapi memancarkan nilai-nilai Ilahiyah, seperti nilai keadilan, persamaan, kemaslahatan, dan kemanusiaan (tasyri' wad'iy-samawi). Atau sebaliknya pengejawantahan nilai-nilai Ilahiyah ke dalam berbagai spectrum hukum modern manusia (tasyri' samawiwad'iy).

Jika hal ini sudah disepakati, maka langkah selanjutnya adalah menyamakan bahasa hukum antara fiqh dan hukum modern. Dalam hal ini fiqh harus berbesar hati untuk menyesuaikan diri dengan terma-terma hukum modern kontemporer tetap menggelinding tanpa henti, sementara terma fiqh sudah membeku sejak abad keempat hijriah.

Oleh karena pendekatan dalam studi hukum modern melibatkan pendekatan ilmu-ilmu social (social sciences approach) maka tidak ada alasan bagi studi hukum islam untuk menerima kehadiran sosiologi, antropologi, sejarah dan lain-lain dalam kajiannya. Hal ini akan melahirkan perwajahan baru hukum Islam yaitu hukum yang formal-tekstual-real dan tidak lagi terpinggirkan atau dipandang sebelah mata. 


\section{DAFTAR PUSTAKA}

Abdullah, M. Amin Dasar-dasar Epistemologi (Pergseran Pemikiran Epistemologi dari Era Modern ke Era Kontemporer). Yogyakarta: Pustaka Pelajar, 1999.

Amal, Taufik Adnan.Islam dan Tantangan Modernitas, Studi Atas Pemikiran Fazlur Rahman. Bandung: Mizan, 1989.

Abdul Hamid, Nizamuddin.Mafhum al-Figh al-Islamiy. Beirut: Muassasah al-Risalah, 1985.

Coulson, NJ. A History of Islamic Law. Bandung: Edinburg: Edinburg University Press, 1998.

Departemen Agama RI.Al-Qur'an dan Terjemahnya. Semarang: Toha Putra, 1989.

Gibb, H. A. R. Mohammedanism: An History Survey. London: Oxford University Press, 1989.

Hassan, A. Pintu Ijtihad Sebelum Tertutup. Bandung: Pustaka, 1997.

al-Jabiry, Muhammad Abid.Bunyah al-'Aql al-'Araby. Beirut: al-Markaz al-Tsaqfa al-'Araby, 1979.

Maslehuddin, M. Philosophy of Islamic Law and Orientalist. Delhi: Taj Company, 1986.

Schacht, Joseph.An Introduction to Islamic Low. London: Oxford University Press, 1971.

As-Sayyis, Muhammad Ali.Tarikh Tasyri' al-Islamiy. Mesir:

Maktabah Muhammad Abi Sabih wa Audah, 1975.

Suriasumantri, Jujuj S. Filsafat Ilmu Sebuah Pengantar Populer. Jakarta: Sinar Harapan, 1997.

al-Qadry, Anwar.Islamic Jurispudence in The Modern World. Lahore: Ashraf Press, 1997. 